\title{
IUGS/IAGC Working Group on Global Geochemical Baselines
}

\author{
http://www.bgs.ac.uk/IUGS
}

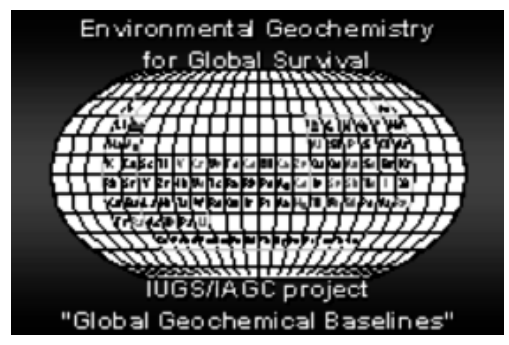

\section{Background}

There is worldwide concern about the potentially damaging effects of chemicals in the environment on the health of humans, animals, agriculture and ecosystems. Economic and population growth are increasing rapidly, exacerbating such problems as land degradation and pollution from uncontrolled urbanisation, intensive agriculture and over-cropping, and over-exploitation of aquifers. These and other problems are having an impact on the chemistry of the Earth's surface and the sustainability of its life-support systems from the local to global scale.

Systematic geochemical mapping is the best method available to assess and provide a basis for monitoring changes in the levels of chemical elements at the Earth's surface. Geochemical maps have traditionally been valuable in addressing a whole range of environmental problems, as well as for identifying potential mineral resources at the local to national scale. Several decades of geochemical mapping by national geological surveys and related organisations throughout the world have resulted in a wealth of valuable information. However, these data cannot be applied to broader regional or global studies because they have been collected using different sampling, analytical and data interpretation methods (Darnley et al., 1995). Part of the reason behind this is that, until recently, there have been no internationally agreed standards for geochemical surveys.

Such data could be used if they were normalised to a reference dataset, i.e. a worldwide suite of geochemical samples collected, analysed and interpreted using a universally consistent set of protocols. Each of the available geochemical survey datasets could be normalised to the reference dataset and interpreted across national boundaries in order to identify geochemical features and anomalies with the potential to affect the health of humans, animals and ecosystems.

The Global Geochemical Baselines Working Group has the long-term goal of establishing such a land-surface global geochemical reference network, providing multi-media, multi-element baseline data for a wide range of environmental and resource applications.

\section{Project organisation}

The project is led by a Steering Committee which co-ordinates the activities of five Technical Committees and contributions made by individual country representatives. The composition of the Steering Committee is as follows:

\section{Honorary President}

Dr Arthur Darnley, Geological Survey of Canada

\section{Co-Leaders}

Prof Jane Plant, British Geological Survey

Dr David Smith, US Geological Survey

Scientific Secretary

Mr Shaun Reeder, British Geological Survey

Treasurer

Dr Tony Reedman, British Geological Survey
The first of the Technical Committees is the Analytical Committee, chaired by Gwendy Hall of the Geological Survey of Canada. This committee is responsible for co-ordinating the work plan for the analysis of the geochemical samples, the activities of the laboratories, and the supervision of analytical quality control data.

Professor Reijo Salminen of the Geological Survey of Finland chairs both the Regional Co-ordination Committee, with responsibility for co-ordinating the project activities of contributing countries worldwide, and the Sampling Committee, with responsibility for supervising the development and co-ordination of sampling protocols in the various climatic and geomorphic provinces throughout the world.

The Data Management Committee, chaired by Timo Tarvainen of the Geological Survey of Finland, is responsible for supervising sampling strategy, co-ordinating the sampling progress of the participating countries, and managing the database of sample information and analytical results.

Finally, the committee on Public Relations and Finance is chaired by Alecos Demetriades of the Institute of Geology and Mineral Exploration (IGME), Greece. This committee is active in advertising and promoting the aims, objectives and achievements of the project worldwide, including by use of the World Wide Web; it also takes responsibility for raising funds for the project.

\section{Project history and objectives}

The project has been active since 1988, and is currently in its third phase. Initially the project was part of the International Geological Correlation Programme (IGCP), Project 259: International Geochemical Mapping, under the leadership of Dr AG Darnley of the Geological Survey of Canada. This first phase concluded with the publication of UNESCO Report 19 (Darnley et al., 1995) detailing the recommendations for a Global Reference Network (GRN) and the basic principles needed to achieve a global geochemical database of lasting value. These included:

- commonly available representative sample media, collected in a standardised manner;

- continuity of data across different landscape types;

- adequate quantities of the sample media for future reference and research requirements;

- analytical data for all elements of environmental or economic significance;

- the lowest possible detection limits for all elements;

- strict quality control at every stage of the process.

From 1993 to 1997, the project continued under the IGCP as Project 360: Global Geochemical Baselines. The design of the GRN was developed and sampling sites selected in a statistically random way based on a grid system which covered the Earth's land surfaces with $160 \times 160 \mathrm{~km}$ grid cells. Standardised methods for geochemical sampling, analysis and data management, agreed by the representatives of more than 100 countries, were 
also prepared during this phase of the project. More detailed methods for sampling in temperate and glaciated terrains were published in a Field Manual (Salminen et al., 1998). Work to develop similar manuals for tropical and arid climates and to provide more detailed descriptions of the analytical methods included in Darnley et al. (1995) is underway.

Following the completion of the first two phases of the IGCP projects, the IUGS, in collaboration with the IAGC, established the current Working Group on Global Geochemical Baselines. The Working Group's main objective for this phase has been to encourage the population of the GRN worldwide through application of the sampling, analytical and data management protocols established in the earlier phases of the project.

\section{Current status and achievements of the Project}

GRN sampling and analysis has been undertaken in several countries worldwide. The GRN of geochemical samples has been completed for China and parts of Russia. Australia is carrying out an airborne gamma ray survey of the whole country as a component of the project. A considerable amount of progress has also been made in Southern Africa, Colombia, Brazil, Korea, India, the USA and many other countries. A major new campaign under the auspices of the Coordinating Committee for Geoscience Programmes in East and Southeast Asia is currently in the planning stages. In more general terms, geological survey organisations worldwide are increasingly using the standard protocols established as part of the project, including as part of their Aid programmes.

Some of the most significant progress has been achieved within Europe. As a contribution to the global project, the Forum of European Geological Surveys (FOREGS) established a Working Group on Geochemical Baselines, led initially by Professor Jane Plant of the British Geological Survey between 1994 and 1996 (Plant et al., 1995) and subsequently by Professor Reijo Salminen of the Geological Survey of Finland. Samples from approximately 700 sub-sites identified on the Global Reference Network within Europe have been collected using the standardised methods given by Darnley et al. (1995) and Salminen et al. (1998). A suite of geochemical samples, including stream water, stream sediment, A-horizon soil, C-horizon soil, floodplain sediment and humus were collected at each sub-site by each participating country. Chemical analysis of the samples is almost complete, and data are being collated and examined for error by the Geological Survey of Finland. Provisional maps have been prepared and all of the participating countries are in the process of interpreting the data. Results will be presented at the Third Conference on Environmental Geochemical Baseline Mapping in Europe, to be held at the Sixth International Symposium on Environmental Geochemistry in Edinburgh, Scotland, in September 2003. In addition, a workshop on Global Geochemical Baselines will be held at the 32nd International Geological Congress in Florence, Italy, in August 2004. It is also anticipated that the Working Group will publish a Geochemical Atlas of Europe in 2004.

\section{Contacts}

Further information about the Working Group's activities may be obtained through the website maintained by the British Geological Survey at http://www.bgs.ac.uk/IUGS , or through the Group's Scientific Secretary, Shaun Reeder (e-mail: sre@bgs.ac.uk).

\section{References}

Darnley A G, et al. 1995. A Global Geochemical Database for Environmental and Resource Management: Recommendations for International Geochemical Mapping. Final Report of IGCP Project 259. Earth Sciences 19, UNESCO, Paris.

Plant J A, Klaver, G, Locutura J, Salminen R, Vrana K and Fordyce F M. 1995. Forum of European Geological Surveys (FOREGS) Geochemistry Task Group 1994-1996 Report: A contribution to the IUGS Continental Geochemical Baselines. British Geological Survey Technical Report Number WP/95/14.

Salminen R, et al. 1998. FOREGS Geochemical Mapping Field Manual. Geological Survey of Finland Guide Number 47.

\author{
Shaun Reeder \\ British Geological Survey, \\ Keyworth, Nottingham, NG12 $5 G G$, \\ $U K$ \\ e-mail:sre@bgs.ac.uk
}

\section{Jane A Plant}

British Geological Survey,

Keyworth, Nottingham, NG12 5GG,

$U K$

David B Smith

US Geological Survey,

PO Box 25046,

MS 973 Denver Federal Center,

Denver, CO 80225.

USA 